\title{
Genetic diversity and phylogeny of rhizobia isolated from agroforestry legume species in southern Ethiopia
}

\author{
Endalkachew Wolde-meskel, ${ }^{1} \dagger$ Zewdu Terefework, ${ }^{2}$ Åsa Frostegård ${ }^{1}$ \\ and Kristina Lindström² \\ ${ }^{1}$ Norwegian University of Life Sciences, Department of Chemistry, Biotechnology and \\ Food Science, PO Box 5040, N-1432 Ås, Norway \\ ${ }^{2}$ Department of Applied Chemistry and Microbiology, Biocenter 1, FIN-0014 University \\ of Helsinki, Finland
}

Correspondence

Endalkachew Wolde-meskel endaw@post.umb.no or ewm_endalkachew@yahoo.com

\section{INTRODUCTION}

Rhizobia are soil bacteria that are capable of forming nitrogen-fixing symbiosis with leguminous plants. The family Leguminosae comprises about 650 genera and 18000 species, and includes short-lived annual herbs and woody perennials that are distributed over a wide range of ecological conditions (Doyle, 1994). Many of its members are of

tPresent address: Debub University, Awassa College of Agriculture, Department of Plant Sciences, PO Box 5, Awassa, Ethiopia.

Abbreviation: ITS, internal transcribed spacer.

The GenBank/EMBL/DDBJ accession numbers for the 16S rRNA gene sequences of strains included in this study are given in Table 1.

UPGMA dendrograms based on combined distance matrices from PCR-RFLP of $16 S$ and 23S rRNA genes and RFLP analysis of PCRamplified 23S rRNA genes, and data on the grouping of the Ethiopian rhizobial isolates and reference strains with various molecular biological methods are available as supplementary material in IJSEM Online. considerable agricultural and ecological importance, generally reflecting the beneficial symbiotic association with rhizobia. In sub-Saharan Africa, woody legumes are an integral part of traditional agroforestry systems and are considered to be low-cost alternatives to fertilizers for soil fertility improvement and land reclamation (Giller, 2001).

Currently, there are 44 recognized species of noduleforming bacteria on legumes, within 12 genera, 10 of which belong to the class 'Alphaproteobacteria' (Allorhizobium, Azorhizobium, Blastobacter, Bradyrhizobium, Devosia, Ensifer, Mesorhizobium, Methylobacterium, Rhizobium and Sinorhizobium), and two to the class 'Betaproteobacteria' (Burkholderia and Ralstonia) (Sawada et al., 2003). In the last few years, many studies investigating rhizobia isolated from tree legumes in East Africa (notably Kenya and Sudan) have revealed considerable phenotypic and genetic diversity among strains, and several distinct groups have been identified and novel species described (Zhang et al., 1991; 
Odee et al., 1997, 2002; Nick et al., 1999; McInroy et al., 1999). However, despite its designation as a centre of diversity and origin of some of the major legume crops, such as pea, lentils, clover and chickpea (Raven \& Polhill, 1981), no information is available on rhizobia from Ethiopia, except for a recent article by Beyene et al. (2004), in which a unique natural rhizobial population that nodulates Phaseolus vulgaris was reported. Exploration of new biogeographical regions and the investigation of legumes that have not been checked for nodulation not only helps to uncover unknown rhizobia, but also supports research efforts aimed at selecting effective combinations of rhizobium-legume genotype to exploit the enormous potential of increased nitrogen fixation. In view of this, we previously surveyed the nodulation status of a variety of indigenous and exotic woody legumes in 14 ecologically diverse zones in southern Ethiopia, and isolated a large number of root-nodulating bacteria (Wolde-meskel et al., 2004a). The strains were phenotypically diverse and comprised several metabolically and genomically distinct groups that were not related to reference rhizobial species (Wolde-meskel et al., 2004a, b, c).

In this study, the strains were characterized by using PCR-RFLP of the 16S rRNA gene, the internal transcribed spacer (ITS) and the 23S rRNA gene, and partial 16S rRNA gene sequencing, and their genetic diversity and phylogenetic relationships were determined. To infer the phylogenetic relatedness of the unknown strains, the $16 \mathrm{~S}$ rRNA gene sequences of currently recognized nitrogen-fixing root/ stem nodule bacterial species were retrieved from the GenBank/EMBL database and included in the analysis.

\section{METHODS}

Bacterial strains. The 223 strains (195 novel isolates and 28 reference strains) used are listed in Tables 1 and 2 and Supplementary Tables S1 and S2 in IJSEM Online. The Ethiopian strains were isolated as described previously (Wolde-meskel et al., 2004a) from naturally occurring root nodules of 15 woody species (indigenous and introduced) and three herbaceous legumes, growing either in the field or under greenhouse conditions in soil samples from diverse agroecological zones in southern Ethiopia. The indigenous woody legumes included Acacia abyssinica, Acacia senegal, Acacia seyal, Acacia tortilis, Albizia gummifera, Erythrina brucei, Faidherbia albida, Millettia ferruginea and Sesbania sesban, whereas the introduced species were Acacia saligna, Cajanus cajan, Calliandra calothyrsus, Gliricidia sepium, Leucaena diversifolia and Leucaena leucocephala. The herbaceous species were Phaseolus vulgaris, Vicia faba and Vigna unguiculata.

Growth of bacteria and DNA isolation. Bacteria were grown on yeast extract mannitol broth at $28^{\circ} \mathrm{C}$ for 3-8 days depending on the strain (Somasegaran \& Hoben, 1994). Total genomic DNA was isolated from $1.5 \mathrm{ml}$ cultures according to Boom et al. (1990) with slight modifications (Terefework et al., 2001), where diatomaceous earth or Celite analytical filter aid (BDH) was used as a DNAbinding solid support. The concentrations were estimated by comparing the DNA samples with known concentrations of $\lambda$ DNA using agarose gel electrophoresis.

PCR-RFLP of the ITS, and 16S and 23S rRNA genes. PCR of the 16S rRNA gene was carried out with primers $\mathrm{fD} 1$ and $\mathrm{rDl}$
(Weisburg et al., 1991), as described by Zhang et al. (1999b), whereas the $23 \mathrm{~S}$ rRNA gene was amplified with primers $3\left(5^{\prime}\right.$ CCGTGAGGGAAAGGTGAAAAGTACC-3') and 4 (5' ${ }^{\prime}$-CCCGCTTAGATGCTTTCAGC-3'), as described previously (Terefework et al., 1998). For amplification of the ITS, we used primers FGPS1490-72 and FGPL132', as described by Normand et al. (1992). DNA amplification was performed by using a PTC-200 Peltier thermal cycler (MJ Research); the cycling profile used was according to Zhang et al. (1999b). The size of the amplification products was verified by electrophoresis in $1 \%$ agarose gels. Aliquots of $8-12 \mu$ lof the amplified $16 \mathrm{~S}$ and $23 \mathrm{~S}$ rRNA genes were digested with $1.5 \mathrm{U}$ of each of the restriction endonucleases AluI, HaeIII, MspI and MboI, at $37^{\circ} \mathrm{C}$ overnight. The ITS region was restricted with the first three enzymes. The digested rRNA genes were separated in $3 \%$ agarose gels.

Partial 16S rRNA gene sequencing. Based on the PCR-RFLP results, 67 test strains were chosen for partial sequencing of the $16 \mathrm{~S}$ rRNA gene, which was performed directly from PCR products (800 bp for 57 strains and $1350 \mathrm{bp}$ for the other 10). The 16S rRNA genes were amplified as described by Zhang et al. (1999a), except that primers $\mathrm{pA}\left(5^{\prime}\right.$-AGAGTTTGATCCTGGCTCAG-3') and $\mathrm{pF}^{\prime}$ $\left(5^{\prime}\right.$-ACGAGCTGACGACAGCCATG-3') were used for the first 57 strains, and primers $1 \mathrm{~F}$ ( $5^{\prime}$-GAGTTTGATCCTGGCTCAG-3'), 15F (5'-ACGGGAGGCAGCAGT- $\left.3^{\prime}\right)$ and 16F (5'-AACTCAAATGAATTFGACGGG-3') were used for the other 10 strains. The amplified fragments were sequenced from both strands by using the solid-phase method, with an automatic laser fluorescence DNA sequencer (Pharmacia). The quality of the sequences was verified by sequencing both strands. These sequences were added to the GenBank/EMBL/DDBJ database (Table 1).

Data analysis. Analysis of the restriction fragments and construction of dendrograms were performed as described by Terefework et al. (1998). During separation of the fragments by agarose gel electrophoresis, the smaller fragments (100 bp or less) appeared diffuse and therefore were not used in the RFLP analysis. The CLUSTAL_X (version 1.83) program (Thompson et al., 1997) was used to align the sequences, and phylogenetic trees were constructed using the neighbour-joining method in MEGA program version 2.1 (Kumar et al., 2001). The trees were displayed using TreeView, as described by Zhang et al. (1999a). The 16S rRNA gene sequences of the type strains of the various genera used in this study were retrieved from the GenBank/EMBL database and used for cladistic analysis. The stability of the groupings was estimated by bootstrap analysis on 100 trees in the same package.

\section{RESULTS AND DISCUSSION}

\section{Characterization by 165 rRNA and 235 rRNA PCR-RFLP}

PCR of the $16 \mathrm{~S}$ rRNA and $23 \mathrm{~S}$ rRNA gene loci from each of the strains produced a single band of 1.5 and $2.3 \mathrm{~kb}$ fragments, respectively, which correspond to the expected size reported previously (Weisburg et al., 1991; Terefework et al., 1998). The grouping of representative strains by using these methods, as well as the Biolog and AFLP data reported previously (Wolde-meskel et al., 2004b, c), are presented in Tables 1 and 2 (data for all strains are given in Supplementary Tables S1 and S2 in IJSEM Online). Fingerprints of the strains generated by PCR-RFLP of the ribosomal genes were used to construct dendrograms by using UPGMA analysis in the Bionumerics software 
Table 1. Representative Ethiopian rhizobial isolates and their grouping results with various molecular biological methods

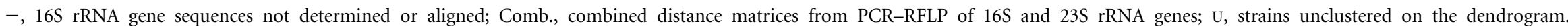
GenBank/EMBL/DDBJ database accession numbers given are from this study. Biolog and AFLP groupings are from Wolde-meskel et al. (2004b, c).

\begin{tabular}{|c|c|c|c|c|c|c|c|c|c|c|c|}
\hline \multirow[t]{2}{*}{ Strain $^{*}$} & \multirow{2}{*}{$\begin{array}{l}\text { Host plant } \\
\text { (provenance) }\end{array}$} & \multirow{2}{*}{$\begin{array}{c}\text { Geographical } \\
\text { origin } \dagger\end{array}$} & \multirow{2}{*}{$\begin{array}{l}\text { Accession } \\
\text { no. }\end{array}$} & \multicolumn{4}{|c|}{ PCR-RFLP genotype } & \multirow[t]{2}{*}{ Biolog } & \multirow[t]{2}{*}{ AFLP } & \multirow{2}{*}{$\begin{array}{l}\text { Closest partial 16S } \\
\text { rRNA gene sequence }\end{array}$} & \multirow{2}{*}{$\begin{array}{c}\text { Similarity } \\
(\%)\end{array}$} \\
\hline & & & & $16 S$ & $23 S$ & Comb. & ITS & & & & \\
\hline AC22d (10) & Acacia seyal, Acacia tortilis & NZ, RFC & AY776185 & 1 & 7 & 9 & $8,9,10,11,23$ & $1 \mathrm{C}-1 \mathrm{E}, 3$ & $6 \mathrm{~B}, 7$ & Sinorhizobium fredii & 100 \\
\hline $\mathrm{AC} 18 \mathrm{a}(4)$ & Acacia seyal, Acacia tortilis & DZ, RFC & AY776180 & 2 & 7 & 10 & $8,11,12$ & $\mathrm{U}, 3$ & 7 & Sinorhizobium fredii & 100 \\
\hline AC24d1 (2) & Acacia tortilis (Mega) & $\mathrm{DZ}$ & - & 3 & 16 & 7 & 19 & 5 & 5 & Sinorhizobium sp. $\ddagger$ & - \\
\hline $\mathrm{AC} 27 \mathrm{c}(4)$ & Acacia tortilis (Meki) & $\mathrm{DZ}$ & - & 4 & 7 & 11 & 24 & $1 \mathrm{C}, 1 \mathrm{D}$ & 7 & Sinorhizobium sp. $\ddagger$ & - \\
\hline AC27e (3) & Acacia tortilis (Meki) & $\mathrm{DZ}$ & AY776187 & 5 & 7 & 11 & 24 & $1 \mathrm{C}, 1 \mathrm{D}, 4$ & 7 & Sinorhizobium fredii & 100 \\
\hline AC01b (14) & Acacia seyal (four provenances) & DZ, NZ, RFC & AY776181 & 6 & $4,5,8$ & $1,2,3$ & $2,22,82$ & 1B-4, U & $6 \mathrm{~A}, 7$ & Sinorhizobium saheli & 99 \\
\hline AC20b & Acacia tortilis (Arba-minch) & $\mathrm{AK}$ & AY776182 & 7 & 16 & 8 & 18 & $1 \mathrm{~A}$ & 5 & Sinorhizobium fredii & 100 \\
\hline AC10d (3) & Acacia seyal (two provenances) & $\mathrm{ACA}, \mathrm{DZ}, \mathrm{NZ}$ & AY776178 & 8 & 2,17 & 5,6 & $17,21,46$ & $1 \mathrm{~A}, 1 \mathrm{~B}, \mathrm{U}$ & 5 & Sinorhizobium fredii & 100 \\
\hline AC10a1 (3) & Acacia seyal (two provenances) & $\mathrm{ACA}, \mathrm{NZ}$ & AY776177 & 9 & 6 & 4 & 98,99 & $1 \mathrm{~A}, 2 \mathrm{~B}, \mathrm{U}$ & 4 & Sinorhizobium saheli & 99 \\
\hline AC38b2 (3) & Acacia abyssinica & $\mathrm{AK}, \mathrm{DZ}$ & AY776190 & 10 & 27,30 & 19,21 & 16,126 & $1 \mathrm{~A}, 1 \mathrm{D}$ & $6 \mathrm{~B}, 7$ & Sinorhizobium saheli & 99 \\
\hline AC38d1 (2) & Acacia abyssinica & $\mathrm{AK}$ & - & 11 & 28 & 22 & 20 & 1B & 5 & Sinorhizobium sp. $\ddagger$ & - \\
\hline $\mathrm{AC} 47 \mathrm{c}$ & Sesbania sesban & $\mathrm{AM}$ & AY776196 & 12 & 12 & 28 & 125 & $\mathrm{U}$ & 7 & Sinorhizobium fredii & 100 \\
\hline AC52c (3) & Sesbania sesban & ACA & AY776201 & 15 & 10 & 27 & 81 & 12 & 3 & Sinorhizobium meliloti & 99 \\
\hline AC52a1 (3) & Sesbania sesban & ACA & - & 18 & 9 & 26 & 81 & 12 & 3 & Sinorhizobium sp. $\ddagger$ & - \\
\hline AC50e (2) & Sesbania sesban & $\mathrm{DZ}$ & AY776199 & 19 & 43 & 25 & 73 & $2 \mathrm{~A}$ & 8 & Sinorhizobium meliloti & 100 \\
\hline AC28a (2) & Acacia tortilis (Meki) & RFC & AY776188 & 20 & 29 & 23 & 4 & $2 \mathrm{~B}$ & 12 & Sinorhizobium medicae & 99 \\
\hline AC25d & Acacia tortilis (Mega) & RFC & - & 21 & 1 & 12 & 7 & $2 \mathrm{~B}$ & 12 & Sinorhizobium sp. $\ddagger$ & - \\
\hline AC07b1 (5) & Acacia seyal (three provenances) & RFC & - & 22 & 3,5 & 14,15 & $1,6,25$ & $2 \mathrm{~A}, 2 \mathrm{~B}, 12$ & 3,12 & Sinorhizobium sp. $\ddagger$ & - \\
\hline $\mathrm{AC} 17 \mathrm{~d}(2)$ & Acacia seyal, Acacia tortilis & RFC & - & 23 & 1 & 13 & 5 & $2 \mathrm{~B}$ & 12 & Sinorhizobium sp. $\ddagger$ & - \\
\hline AC47a (3) & Sesbania sesban & $\mathrm{AM}$ & AY776195 & 24 & 36 & 29 & 113 & 13 & 2 & Ensifer adhaerens & 99 \\
\hline $\mathrm{AC} 82 \mathrm{~b}(4)$ & Albizia gummifera, Vicia faba & ACA & AY776222 & 25 & 60 & 34 & 33 & $\mathrm{U}, 1,6$ & 5 & Rhizobium leguminosarum & 100 \\
\hline $\mathrm{AC} 100 \mathrm{~b}$ & Acacia senegal & LK & AY776212 & 26 & 21 & 40 & 101 & 9 & $\mathrm{U}$ & Rhizobium leguminosarum & 99 \\
\hline $\mathrm{AC} 100 \mathrm{a}$ & Acacia senegal & LK & AY776243 & 27 & 53 & 32 & 100 & 1 & 6 & Rhizobium leguminosarum & 100 \\
\hline AC56b & Vigna unguiculata & $\mathrm{AK}$ & AY776202 & 32 & 54 & 33 & 86 & $\mathrm{U}$ & $1 \mathrm{~B}$ & Rhizobium etli & 100 \\
\hline AC04d & Acacia seyal (Abergele) & RFC & AY776198 & 33 & 58 & 31 & 88 & $\mathrm{U}$ & 2 & Rhizobium etli & 99 \\
\hline AC87k1 (2) & Millettia ferruginea & ACA & AY776226 & 34 & 59 & 30 & 31 & 14 & 25 & Rhizobium etli & 100 \\
\hline AC90e1 (5) & G. sepium & ACA & AY776234 & 35 & 19 & 44 & 43 & 5 & 4 & Rhizobium mongolense & 99 \\
\hline AC91e (2) & Calliandra calothyrsus & ACA & AY776235 & 36 & 18,19 & 45 & 28,42 & 1,3 & 8,18 & Rhizobium mongolense & 99 \\
\hline AC89a (6) & L. leucocephala & ACA & - & 37 & 19 & 46 & 28,42 & $1,3,4$ & 3,8 & Rhizobium sp. $\neq$ & - \\
\hline $\mathrm{AC} 80 \mathrm{a}(5)$ & L. diversifolia & ACA & - & 38 & 24 & 42 & 30 & 1 & 8 & Rhizobium sp. $\neq$ & - \\
\hline AC86c1 (2) & Cajanus cajan & ACA & AY776225 & 39 & 61 & 43 & 35 & 9 & 9 & Rhizobium sp. & 98 \\
\hline AC93e (5) & G. sepium & RFC & AY776238 & 40 & 23 & 41 & 29 & 4 & 8 & Rhizobium mongolense & 99 \\
\hline AC86a & Cajanus cajan & ACA & AY776223 & 41 & 20 & 47 & 34 & 10 & 5 & Rhizobium sp. & 98 \\
\hline
\end{tabular}


Table 1. cont.

\begin{tabular}{|c|c|c|c|c|c|c|c|c|c|c|c|}
\hline \multirow[t]{2}{*}{ Strain $^{\star}$} & \multirow{2}{*}{$\begin{array}{l}\text { Host plant } \\
\text { (provenance) }\end{array}$} & \multirow{2}{*}{$\begin{array}{l}\text { Geographical } \\
\text { origin } \dagger\end{array}$} & \multirow{2}{*}{$\begin{array}{l}\text { Accession } \\
\text { no. }\end{array}$} & \multicolumn{4}{|c|}{ PCR-RFLP genotype } & \multirow[t]{2}{*}{ Biolog } & \multirow[t]{2}{*}{ AFLP } & \multirow{2}{*}{$\begin{array}{l}\text { Closest partial 16S } \\
\text { rRNA gene sequence }\end{array}$} & \multirow{2}{*}{$\begin{array}{c}\text { Similarity } \\
(\%)\end{array}$} \\
\hline & & & & $16 S$ & $23 S$ & Comb. & ITS & & & & \\
\hline AC26e & Acacia tortilis (Meki) & AK & AY776186 & 44 & 55 & 50 & 111 & $\mathrm{U}$ & $1 \mathrm{~B}$ & Rhizobium sp. & 97 \\
\hline AC87k3 & Millettia ferruginea & ACA & AY776227 & 45 & 62 & 51 & 27 & $\mathrm{U}$ & 9 & Rhizobium sp. & 97 \\
\hline $\mathrm{AC} 88 \mathrm{c}$ & Acacia abyssinica & $\mathrm{ACA}$ & AY776232 & 46 & 79 & 87 & 117 & $\mathrm{U}$ & $\mathrm{U}$ & Mesorhizobium chacoense & 98 \\
\hline $\mathrm{AC} 88 \mathrm{a}$ & Acacia abyssinica & ACA & AY776231 & 47 & 46 & 52 & 97 & 11 & 19 & Rhizobium giardinii & 99 \\
\hline $\mathrm{AC} 79 \mathrm{cl}$ & Erythrina brucei & ACA & AY776219 & 51 & 52 & 57 & 90 & 8 & 2 & Agrobacterium radiobacter & 100 \\
\hline $\mathrm{AC} 42 \mathrm{c}$ & Acacia abyssinica & RFC & AY776194 & 52 & 39 & 65 & 115 & 7 & 8 & Agrobacterium tumefaciens & 99 \\
\hline AC97c1 (2) & Acacia saligna & WG & AY776241 & 54 & 38 & 63 & 47 & 13 & 3 & Agrobacterium vitis & 99 \\
\hline $\mathrm{AC} 77 \mathrm{~b}$ & Acacia senegal & RFC & AY776218 & 56 & 51 & 56 & 36 & $\mathrm{U}$ & $\mathrm{U}$ & 'Agrobacterium albertimagni' & 99 \\
\hline AC11a (3) & Acacia seyal (two provenances) & ACA, DZ & AY776179 & 57 & 63 & 54 & 26,112 & 8 & $\mathrm{U}$ & 'Agrobacterium albertimagni' & 99 \\
\hline AC51e (9) & Sesbania sesban, Vigna unguiculata & $\mathrm{NZ}$ & AY776200 & 60 & $37,40,41$ & 58,60 & $40,41,116$ & $6 \mathrm{~A}, 6 \mathrm{~B}$ & $1 \mathrm{~A}, 1 \mathrm{~B}$ & Rhizobium huautlense & 99 \\
\hline AC73d (6) & Phaseolus vulgaris & $\mathrm{DZ}$ & AY776210 & 61 & 50 & 61 & 37 & $6 \mathrm{~A}, 6 \mathrm{~B}$ & $1 \mathrm{~A}, 1 \mathrm{~B}$ & Rhizobium huautlense & 100 \\
\hline AC100e (2) & Acacia senegal & LK & AY776213 & 67 & 72 & 78 & 50,77 & 2 & 15 & Mesorhizobium plurifarium & 99 \\
\hline AC39a $(6)$ & Acacia abyssinica, Acacia tortilis & $\mathrm{CF}, \mathrm{RFC}$ & AY776191 & 68 & $64-68$ & $70-74$ & $52,54,119-121$ & $\mathrm{U}, 9,14$ & 4,10 & Mesorhizobium plurifarium & 99 \\
\hline AC99a (4) & Sesbania sesban & WG & - & 69 & $72-74$ & 76,77 & $48-50,118$ & 2,12 & 12,24 & Mesorhizobium sp. $\ddagger$ & - \\
\hline AC99d & Sesbania sesban & WG & AY776211 & 70 & 72 & 75 & 107 & 2 & 24 & Mesorhizobium plurifarium & 99 \\
\hline AC98a & Acacia abyssinica & WG & AY776242 & 71 & 75,76 & 79,80 & $51,74-76$ & $\mathrm{U}$ & 15 & Mesorhizobium plurifarium & 99 \\
\hline $\mathrm{AC} 21 \mathrm{c} 2(2)$ & Acacia tortilis (Arba-minch) & $\mathrm{NZ}$ & AY776184 & 72 & 77,78 & 85,86 & 53,69 & 9 & 8,16 & Mesorhizobium sp. & 99 \\
\hline $\mathrm{AC72a}$ & Phaseolus vulgaris & $\mathrm{CF}$ & AY776209 & 73 & 103 & 114 & 45 & $\mathrm{U}$ & 4 & Methylobacterium sp. & 94 \\
\hline $\mathrm{AC} 101 \mathrm{~b}(3)$ & Acacia saligna & LK & AY776214 & 74 & 88 & 92 & 78 & 15 & 3,10 & Bradyrhizobium liaoningense & 100 \\
\hline $\mathrm{AC} 29 \mathrm{c}$ & F. albida (Arba-minch) & RFC & AY776189 & 76 & 93 & 107 & 65 & 16 & 4 & Bradyrhizobium liaoningense & 100 \\
\hline AC79a (3) & Erythrina brucei & ACA & AY776220 & 77 & 82 & 88 & 57 & 15 & 3 & Bradyrhizobium liaoningense & 100 \\
\hline AC104a (3) & Acacia saligna & $\mathrm{BL}$ & AY776215 & 78 & 86 & 90 & 105 & 18 & 13 & Bradyrhizobium sp. & 99 \\
\hline $\mathrm{AC} 104 \mathrm{cl}(2)$ & Acacia saligna & $\mathrm{BL}$ & AY776216 & 79 & 87 & 91 & 106 & $\mathrm{U}$ & 7 & Bradyrhizobium sp. & 99 \\
\hline AC62a & Vigna unguiculata & DL & AY776203 & 81 & 94 & 99 & 67 & 16 & 1B & Bradyrhizobium japonicum & 99 \\
\hline AC64a (4) & Vigna unguiculata & NZ & AY776204 & 82 & 92,94 & 100,102 & $61,66,68$ & 16 & 4,5 & Bradyrhizobium yuanmingense & 99 \\
\hline AC87b1 (2) & Millettia ferruginea & $\mathrm{ACA}$ & AY776228 & 83 & 99 & 112 & 70 & 16 & 5 & Bradyrhizobium elkanii & 100 \\
\hline AC86b2 (2) & Cajanus cajan & ACA & AY776224 & 84 & 81 & 106 & 55 & 15 & 1 & Bradyrhizobium japonicum & 99 \\
\hline $\mathrm{AC79c2}$ & Erythrina brucei & ACA & - & 85 & 80 & 105 & 57 & 15 & 1 & Bradyrhizobium sp. $\neq$ & - \\
\hline AC82d & Albizia gummifera & $\mathrm{ACA}$ & AY776221 & 86 & 81 & 104 & 55 & 15 & 1 & Bradyrhizobium sp. & 99 \\
\hline AC87h (3) & Millettia ferruginea & $\mathrm{ACA}$ & - & 87 & 81 & 103 & 64 & 15 & 1 & Bradyrhizobium sp. $\ddagger$ & - \\
\hline AC92d (2) & Albizia gummifera & ACA & AY776237 & 88 & 83,89 & 95,96 & 60,62 & 15 & 3 & Bradyrhizobium japonicum & 100 \\
\hline $\mathrm{AC} 70 \mathrm{c}$ & Phaseolus vulgaris & $\mathrm{AK}$ & AY776208 & 89 & 95 & 101 & 58 & 16 & $1 \mathrm{~B}$ & Bradyrhizobium liaoningense & 100 \\
\hline
\end{tabular}


(Fig. 1 and Supplementary Figs S1 and S2 in IJSEM Online). The cophenetic correlation coefficient indicates the consistency of a cluster or the whole dendrogram and calculates the correlation between the dendrogram-derived similarities and the matrix similarities. In this study, cluster analysis based on the Dice coefficient yielded a significantly high mean cophenetic correlation coefficient (generally $>92 \%$ ), suggesting that the level of distortion between the similarity matrix and cluster analysis was low. In 58 strains, the amplified fragments of the ITS existed as multiple copies of variable size (Supplementary Table S1 in IJSEM Online). This rendered the ITS region unsuitable for use for overall comparison of all the strains.

Characterization based on PCR-RFLP of the 16S rRNA gene distinguished 96 different combinations of patterns, representing 96 distinct $16 \mathrm{~S}$ rRNA genotypes among all the strains, including the reference species (Tables 1 and 2). The clustering of the strains in the dendrogram (Fig. 1) was in agreement with previously reported RFLP groupings and phylogenetic trees based on whole 16S rRNA gene sequences for rhizobia (Young \& Haukka, 1996; Terefework et al., 1998; Nick et al., 1999; Gao et al., 2001). The 71 16S rRNA genotypes identified among the test strains corresponded to five major groups (Fig. 1); 78 strains were variously assigned to the Sinorhizobium branch, 49 to Rhizobium, 8 to Agrobacterium, 20 to Mesorhizobium and 40 to the Bradyrhizobium lineage.

Application of the 23S rRNA gene PCR-RFLP delineated 103 different $23 \mathrm{~S}$ rRNA genotypes among all the strains studied (78 in the test strains and 25 in the reference strains) (Tables 1 and 2, and Supplementary Fig. S1 in IJSEM Online). The $23 \mathrm{~S}$ rRNA gene, because of its large size and greater phylogenetic information content, gives better resolution than the 16S rRNA gene (Terefework et al., 1998; Zhang et al., 1999a; Gao et al., 2001). Discrimination of the test strains into a large number of 23S rRNA genotypes in this study supported previous findings. However, the genotypes defined by RFLP of the $16 \mathrm{~S}$ and $23 \mathrm{~S}$ rRNA genes were in good agreement in most cases. Exceptions were found among isolates of $1216 \mathrm{~S}$ rRNA genotypes $(6,8,10,22$, $36,60,68,69,71,72,82$ and 88 ) that were divided into two or more $23 \mathrm{~S}$ rRNA genotypes, and among strains of $16 \mathrm{~S}$ rRNA genotypes 1, 2, 4 and 5 that belonged to a single $23 \mathrm{~S}$ rRNA genotype, genotype 7 (Table 1 and Supplementary Table S1 in IJSEM Online).

The combined distance matrices of the 16S and 23S rRNA gene PCR-RFLP patterns revealed the diverse nature of our collection more than either gene alone, and thus identified 114 genotypes among the strains ( 87 and 27 genotypes among test and reference strains, respectively). The dendrogram constructed (Supplementary Fig. S2 in IJSEM Online) showed more extensive and deeper branching than either of the $16 \mathrm{~S}$ or $23 \mathrm{~S}$ rRNA gene PCR-RFLP dendrograms. Whereas all but 13 isolates (representing $16 \mathrm{~S}$ rRNA genotypes $25,26,27,46,51,56,57$ and 73 ) were classified into the same taxonomic groups as with the 16S rRNA gene 
Table 2. Reference strains and their grouping results with various molecular biological methods

Abbreviations: CFN, Centro de Investigación sobre Fijación de Nitrógeno, Universidad Nacional Autónoma de México, Cuernavaca, Mexico; CIAT, CIAT Rhizobium Collection, Centro Internacional de Agricultura Tropical, Columbia; Comb., combined distance matrices from PCR-RFLP of $16 \mathrm{~S}$ and $23 \mathrm{~S}$ rRNA genes; HAMBI, culture collection of the Division of Microbiology, University of Helsinki, Finland; LMG, Laboratorium voor Microbiologie, University of Ghent, Belgium; ORS, IRD/ORSTOM collection, Institut de Recherche pour le Développement, Dakar, Senegal; USDA, US Department of Agriculture, Beltsville, MD, USA; U, strains unclustered on the dendrogram. Sequence accession numbers were retrieved from GenBank/EMBL. Biolog and AFLP groupings are from Wolde-meskel et al. (2004b, c).

\begin{tabular}{|c|c|c|c|c|c|c|c|}
\hline \multirow[t]{2}{*}{ Strain } & \multirow{2}{*}{$\begin{array}{c}\text { Accession } \\
\text { no. }\end{array}$} & \multicolumn{4}{|c|}{ PCR-RFLP genotype } & \multirow[t]{2}{*}{ Biolog } & \multirow[t]{2}{*}{ AFLP } \\
\hline & & $16 S$ & $23 S$ & Comb. & ITS & & \\
\hline Sinorhizobium kostiense HAMBI $1489^{\mathrm{T}}\left(=\mathrm{LMG} 15613^{\mathrm{T}}\right)$ & Z78203 & 13 & 13 & 16 & 91 & $\mathrm{U}$ & 9 \\
\hline Sinorhizobium saheli HAMBI $215^{\mathrm{T}}\left(=\mathrm{ORS} 609^{\mathrm{T}}\right)$ & X68390 & 13 & 11 & 17 & 127 & $1 \mathrm{~A}$ & 9 \\
\hline Sinorhizobium terangae HAMBI $220^{\mathrm{T}}\left(=\mathrm{ORS} 1009^{\mathrm{T}}\right)$ & X68388 & 14 & 14 & 18 & 104 & $2 \mathrm{~A}$ & 11 \\
\hline Sinorhizobium arboris HAMBI $1552^{\mathrm{T}}\left(=\mathrm{LMG} 14919^{\mathrm{T}}\right)$ & Z78204 & 16 & 15 & 20 & 15 & $2 \mathrm{~A}$ & 9 \\
\hline Sinorhizobium medicae HAMBI 1838 (=LMG 16582) & L39882 & 17 & 44 & 24 & 13 & $2 \mathrm{~A}$ & 9 \\
\hline Sinorhizobium meliloti HAMBI $2148^{\mathrm{T}}\left(=\mathrm{LMG} 6133^{\mathrm{T}}\right)$ & X67222 & 17 & 44 & 24 & 14 & $2 \mathrm{~A}$ & 9 \\
\hline Rhizobium leguminosarum HAMBI $12^{\mathrm{T}}$ (=LMG $14904^{\mathrm{T}}$ ) & U29386 & 28 & 56 & 35 & 110 & 15 & $1 \mathrm{~A}$ \\
\hline Rhizobium etli HAMBI $1727^{\mathrm{T}}\left(=\mathrm{CFN} 42^{\mathrm{T}}\right)$ & U28916 & 29 & 57 & 36 & 93 & $\mathrm{U}$ & 11 \\
\hline Rhizobium hainanense HAMBI $1930^{\mathrm{T}}$ & U71078 & 30 & 49 & 39 & 92 & 10 & 9 \\
\hline Rhizobium tropici HAMBI $1163^{\mathrm{T}}\left(=\mathrm{CIAT} 899^{\mathrm{T}}\right)$ & X67234 & 30 & 47 & 37 & 94 & 10 & $\mathrm{U}$ \\
\hline Agrobacterium rhizogenes HAMBI $1816^{\mathrm{T}}\left(=\mathrm{LMG} 150^{\mathrm{T}}\right)$ & X67224 & 31 & 48 & 38 & 87 & 10 & $\mathrm{U}$ \\
\hline Rhizobium mongolense HAMBI $2349^{\mathrm{T}}\left(=\mathrm{USDA} 1844^{\mathrm{T}}\right)$ & U89816 & 42 & 22 & 48 & 44 & $\mathrm{U}$ & 15 \\
\hline Rhizobium gallicum HAMBI $2326^{\mathrm{T}}$ & U86343 & 43 & 26 & 49 & 95 & 15 & 15 \\
\hline Rhizobium giardinii HAMBI $2323^{\mathrm{T}}$ & U86344 & 48 & 45 & 53 & 103 & $\mathrm{U}$ & $\mathrm{U}$ \\
\hline Agrobacterium tumefaciens HAMBI $1811^{\mathrm{T}}\left(=\mathrm{LMG} 187^{\mathrm{T}}\right)$ & X67223 & 49 & 31 & 66 & 102 & 11 & 13 \\
\hline Agrobacterium radiobacter HAMBI $1814^{\mathrm{T}}\left(=\mathrm{LMG} 140^{\mathrm{T}}\right)$ & AJ389904 & 50 & 31 & 67 & 102 & 11 & 13 \\
\hline Agrobacterium rubi HAMBI $1812^{\mathrm{T}}\left(=\mathrm{LMG} 156^{\mathrm{T}}\right)$ & X67228 & 53 & 32 & 68 & 79 & 7 & 8 \\
\hline Agrobacterium vitis HAMBI $1817^{\mathrm{T}}\left(=\mathrm{LMG} 8750^{\mathrm{T}}\right)$ & X67225 & 55 & 34 & 64 & 84 & $\mathrm{U}$ & 13 \\
\hline Rhizobium galegae HAMBI $540^{\mathrm{T}}\left(=\mathrm{LMG} 6214^{\mathrm{T}}\right)$ & X67226 & 58 & 25 & 55 & 80 & $\mathrm{U}$ & $\mathrm{U}$ \\
\hline Rhizobium huautlense HAMBI $2409^{\mathrm{T}}$ & AF025852 & 59 & 35 & 59 & 38 & $6 \mathrm{~B}$ & 16 \\
\hline Allorhizobium undicola LMG $11875^{\mathrm{T}}$ & Y17047 & 62 & 33 & 69 & 83 & 8 & 9 \\
\hline Mesorhizobium ciceri HAMBI $1750^{\mathrm{T}}\left(=\mathrm{LMG} 14989^{\mathrm{T}}\right)$ & U07934 & 63 & 69 & 81 & 123 & $\mathrm{U}$ & 14 \\
\hline Mesorhizobium loti HAMBI $1129^{\mathrm{T}}\left(=\mathrm{LMG} 6125^{\mathrm{T}}\right)$ & X67229 & 64 & 69 & 82 & 122 & $\mathrm{U}$ & 14 \\
\hline Mesorhizobium mediterraneum HAMBI $2096^{\mathrm{T}}$ & L38825 & 65 & 70 & 83 & 89 & $\mathrm{U}$ & $\mathrm{U}$ \\
\hline Mesorhizobium huakuii HAMBI $1674^{\mathrm{T}}$ (=LMG $14107^{\mathrm{T}}$ ) & D12797 & 66 & 71 & 84 & 124 & 7 & 16 \\
\hline Bradyrhizobium japonicum HAMBI $2314^{\mathrm{T}}\left(=\mathrm{USDA} 6^{\mathrm{T}}\right)$ & X66024 & 75 & 96 & 89 & 108 & $\mathrm{U}$ & $\mathrm{U}$ \\
\hline Bradyrhizobium elkanii LMG $6134^{\mathrm{T}}$ & U35000 & 80 & 101 & 110 & 109 & $\mathrm{U}$ & 15 \\
\hline Azorhizobium caulinodans HAMBI $216^{\mathrm{T}}\left(=\mathrm{ORS} 571^{\mathrm{T}}\right)$ & X67221 & 96 & 102 & 113 & 85 & $\mathrm{U}$ & $\mathrm{U}$ \\
\hline
\end{tabular}

PCR-RFLP method, cluster analysis of the combined 16S and $23 \mathrm{~S}$ rRNA PCR-RFLP data resulted in further discrimination of the strains, and hence identified more genotypes within the same taxon. Thus, the number of different genotypes assigned to the Rhizobium branch increased from 20 (16S rRNA genotypes) to 24 (combined $16 \mathrm{~S}$ and $23 \mathrm{~S}$ rRNA genotypes), and from 20 to 24 in the Sinorhizobium branch, 6 to 13 in the Mesorhizobium branch and 20 to 23 in the Bradyrhizobium branch. The moreheterogeneous nature of the isolates that the combined RFLP pattern revealed in the Mesorhizobium branch was remarkable (Supplementary Fig. S2 in IJSEM Online), and supports previous reports on strains belonging to the genus Mesorhizobium (de Lajudie et al., 1998; Zhang et al., 1999a; Wang et al., 2003).
Interestingly, apart from a few isolates, all the test strains in the different taxonomic branches formed a number of tightly clustered, separate subgroups in all the parameters studied (Fig. 1 and Supplementary Figs S1 and S2 in IJSEM Online) and were related to the reference strains at most with $88 \%$ similarity, hence reflecting their distinct genotypic nature. This was supported by the tight and separate clusters that the reference species consistently formed in all the dendrograms constructed (Fig. 1 and Supplementary Figs $\mathrm{S} 1$ and S2 in IJSEM Online). In addition, in previous studies, a large number of test strains $(80 \%)$ in our collection had metabolic and genomic (AFLP) profiles that were not related to reference species (Wolde-meskel et al., 2004b, c). This contrasts with the findings of Odee et al. (2002) and Bala et al. $(2002,2003)$ where, in a study of a large number 


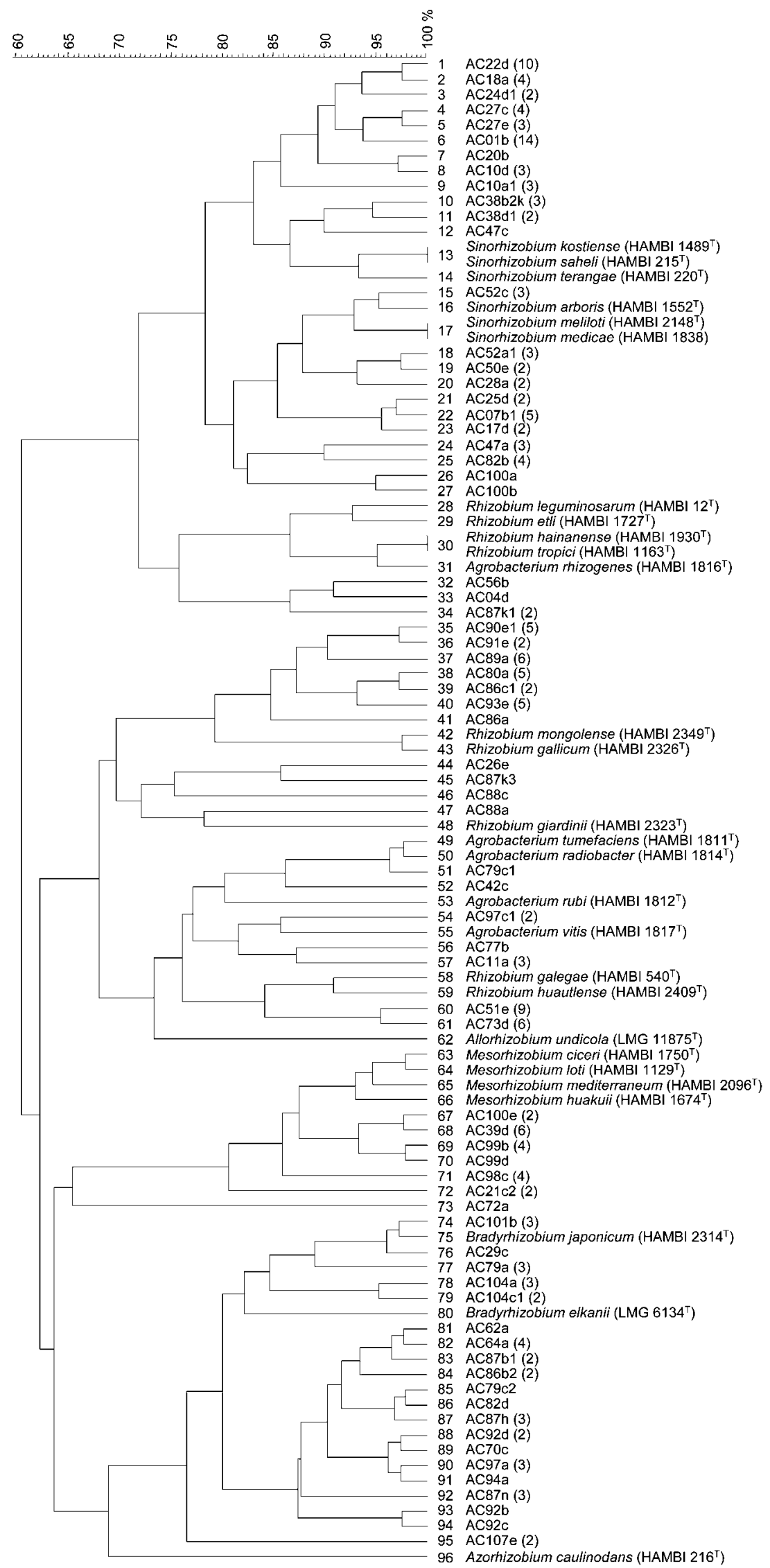

Fig. 1. Dendrogram based on the RFLP analysis of PCR-amplified 16S rRNA genes of test and reference strains. The distinct genotypes are numbered in order of their appearance. Numbers in parentheses indicate the number of strains that had the same restriction pattern (genotypes). The data were clustered by using UPGMA in the Bionumerics program. 


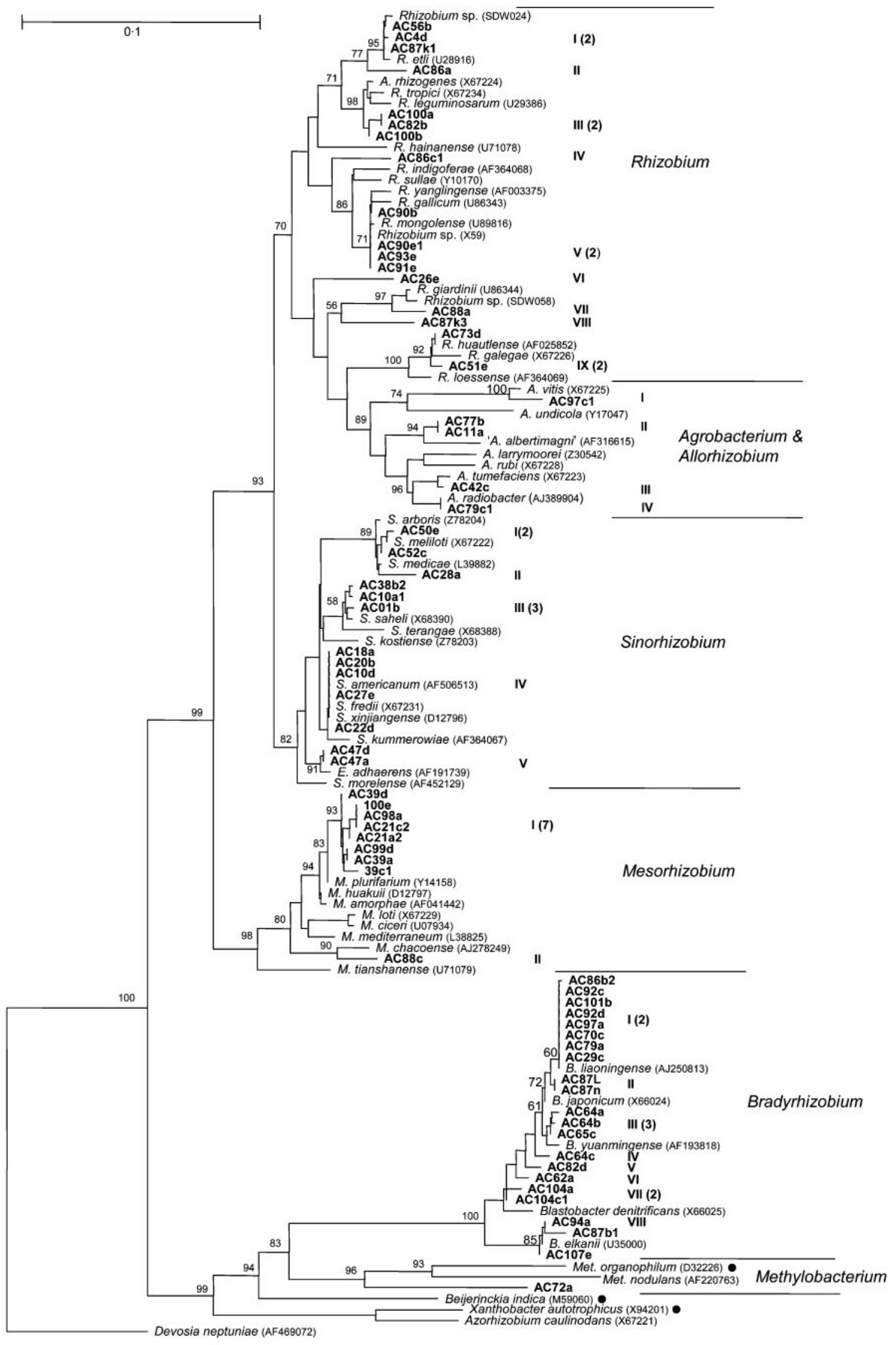


of tree rhizobia isolated from Kenya and southern parts of Africa, many strains had identical $16 \mathrm{~S}$ rRNA genotypes to the reference rhizobial strains included in the study.

\section{Phylogenetic analysis}

To elucidate the taxonomic positions of the isolates, we partially sequenced the 16S rRNA genes of 67 strains representing the various $16 \mathrm{~S}$ rRNA PCR-RFLP genotypes. The aligned sequences of the Ethiopian strains, and those of recognized species of rhizobia, agrobacteria and other related symbiotic and non-symbiotic species, were used in the phylogenetic analysis. The results are presented in Fig. 2, and were consistent with previous reports (Young et al., 2001; Toledo et al., 2003; Sawada et al., 2003). Overall, 46 different $16 \mathrm{~S}$ rRNA gene sequence types representing six genera were found (Fig. 2); 13 were clustered within the Rhizobium branch, 12 within the Bradyrhizobium branch, four within the Agrobacterium branch, eight each within Sinorhizobium and Mesorhizobium and one within the Methylobacterium branch. Twelve of the 46 rRNA genotypes had $100 \%$ partial sequence similarity with one or more species of the first four genera, whereas the other 34 were novel and were related (with $94-99 \%$ similarity) to members of one of these six genera (Table 1 and Supplementary Table S1 in IJSEM Online).

Rhizobium and Agrobacterium branches. Nine of the 13 Rhizobium genotypes (in groups I, III, V, VII and IX; Fig. 2) were typical of previously described species and showed high sequence similarity $(99-100 \%)$ to Rhizobium etli, Rhizobium leguminosarum, Rhizobium mongolense, Rhizobium giardinii and Rhizobium huautlense. However, four $16 \mathrm{~S}$ rRNA gene sequences in groups II, IV, VI and VIII (representing strains AC86a, AC86c1, AC26e and AC87k3, respectively) were distinct, with $16 \mathrm{~S}$ rRNA gene similarities with the most similar published sequences of as low as $97 \%$, a 'threshold' for species delineation (Stackebrandt \& Goebel, 1994), hence possibly representing novel species. Interestingly, several Rhizobium genotypes in this study showed high similarity to nondescribed Rhizobium strains isolated from China.

(i) The two genotypes in group V, which were related to Rhizobium mongolense (99\%) and represented 23 strains isolated from three host species (Supplementary Table S1 in IJSEM Online), instead showed $100 \%$ partial sequence similarity to strain X59, an isolate from Astragalus adsurgens (Gao et al., 2001). In a polyphasic study, Gao et al. (2001) reported that strain X59 had a unique genotype that was closely related to a strain isolated from another Astragalus species, Astragalus membranacens (Wang \& Chen, 1996). (ii) Strains SDW024 and SDW058, which were isolated from Astragalus adsurgens (Gao et al., 2001), and USDA 1920, a strain isolated from Medicago ruthenica in China (van Berkum et al., 1998), had the most similar published sequences found in the database (97-98\%), matching strains AC86a (group II), AC87k3 (VIII) and AC86cl(IV), respectively, in our study.

There is no known documented history of the introduction of rhizobial inoculants from China into Ethiopia, or vice versa, nor, in fact, from any other part of the world. However, because of the highly conserved nature of the $16 \mathrm{~S}$ rRNA gene sequence, the existence of alike genotypes or similar sequences in widely separated geographical regions under varying environmental conditions is to be expected (Martínez-Romero \& Caballero-Mellado, 1996; Moreira et al., 1998). Although allopatry could not be implicated and recombination within and between ribosomal genes has been shown (Young \& Haukka, 1996), it is also possible that divergent evolution in rhizobia took place independently in several locations. A thorough study of the core and accessory genome of these and other Ethiopian isolates might reveal very interesting insights into rhizobial evolution.

The partial sequence analysis of AC26e, a strain isolated from Acacia tortilis, showed a mosaic 16S rRNA gene, which was related (97\%) to Sinorhizobium sp. 9702-M4, a strain reported to synthesize an extracellular polymer that facilitates the transport of hydrophobic pollutants as well as toxic metals, lead and cadmium, in soil (Janeca et al., 2002). However, it formed a separate phylogenetic branch within the genus Rhizobium and showed distinct metabolic reactions in a previous Biolog study (Wolde-meskel et al., 2004b).

Among the eight strains isolated from root nodules of Erythrina brucei and Acacia species, four Agrobacterium genotypes were identified (Fig. 2). These included Agrobacterium radiobacter ( $100 \%$ partial sequence similarity), Agrobacterium tumefaciens (99\%), Agrobacterium vitis (99\%) and 'Agrobacterium albertimagni' (99\%). In previous studies, a large number of strains with $16 \mathrm{~S}$ rRNA gene sequences that were very similar to that of Agrobacterium tumefaciens were isolated from herbaceous (Phaseolus vulgaris and Vigna unguiculata) and tree legume species grown in African soils (Anyango et al., 1995; Khbaya et al., 1998; de Lajudie et al., 1999; Odee et al., 2002; Bala \& Giller, 2001; Bala et al., 2003). A cross-inoculation study conducted to evaluate symbiotic effectiveness (data not presented) showed that the strains were not capable of eliciting nodulation on homologous or other host species, in agreement

Fig. 2. Phylogenetic tree of selected Ethiopian rhizobial strains and related bacteria within the class 'Alphaproteobacteria'. The tree was constructed using the neighbour-joining method from partial 16S rRNA gene sequences. Bootstrap probability values greater than $50 \%$ are indicated at the branch points. Bar, $0 \cdot 1$ substitution per site. Roman numerals indicate groups of different test strains in the respective genus, whereas numbers in parentheses represent the various $16 S$ rRNA gene sequence types in the group. $\bullet$, Closely related but non-symbiotic bacteria. 
with other studies. The agrobacterial isolates that were reported to be capable of infection after isolation from nodules (Bala \& Giller, 2001) thus seem to represent an exception. However, all of our strains except one had novel sequences, with $99 \%$ partial sequence similarity to each of their described counterparts, and were classified in different AFLP and Biolog groups in previous studies (Woldemeskel et al., 2004b, c). In addition, this is the first report of strains with high similarity to 'Agrobacterium albertimagni', an arsenite-oxidizing bacterium from aquatic macrophytes in a hot creek (Salmassi et al., 2002), being isolated from root nodules of plants in African soil.

Sinorhizobium lineage. All representative isolates in this group were phylogenetically affiliated to one of five species: Sinorhizobium fredii, Sinorhizobium meliloti, Sinorhizobium medicae, Sinorhizobium saheli and Ensifer adhaerens (Fig. 2). Although only partial sequences were used, all isolates except those identified as belonging to the species Sinorhizobium fredii had novel 16S rRNA gene sequences, with $99 \%$ sequence similarity to the respective reference species (Table 1). It is interesting to note that, with the exception of 11 strains isolated from Sesbania sesban, all of the other 61 strains associated with the Sinorhizobium branch were isolated from Acacia species (Table 1 and Supplementary Table S1 in IJSEM Online). The type strain of Sinorhizobium terangae was isolated from Sesbania and Acacia species in Senegalese soils (de Lajudie et al., 1994), whereas Sinorhizobium arboris and Sinorhizobium kostiense were isolated from Acacia senegal and Prosopis chilensis, in Kenyan and Sudanese soils, respectively (Nick et al., 1999). Despite extensive sampling that covered a wide range of ecoclimatic and altitudinal zones in Ethiopia (Wolde-meskel et al., 2004a), and the use of the same and/or related trap host species of similar rhizobial affinities, no strains closely related to these genotypes were found. However, two and three different genotypes were represented in Sinorhizobium meliloti and Sinorhizobium saheli, respectively (Fig. 2).

Three strains (AC47a, AC47b and AC47d) that were closely related to Ensifer adhaerens (99\% partial sequence similarity) were isolated from a location (Arba-minch) that is characterized by a high soil $\mathrm{pH}(8 \cdot 6)$ and temperature (Wolde-meskel et al., 2004a). Interestingly, these strains were $100 \%$ similar to an undescribed high-temperature and halotolerant Sinorhizobium species isolated from seaside areas in Taiwan (Chen et al., 2000). This may reflect the role of the habitats of the strains in shaping the rhizobial genotypes, and possibly the in situ population structure of rhizobia (Wang et al., 1999, 2003; Wang \& MartínezRomero, 2000). These strains offer the possibility of enhancing nitrogen fixation in salty-alkaline conditions where the efficiency of rhizobium-legume symbiosis is hampered.

Mesorhizobium branch. Phylogenetic analysis of nine strains, representing 20 isolates in this group (Fig. 2 and
Supplementary Table S1 in IJSEM Online), identified two species, Mesorhizobium chacoense (one strain) and Mesorhizobium plurifarium (eight strains), with 98 and $99 \%$ partial sequence similarities, respectively. However, with the exception of two strains (AC100e and AC98a), which had $100 \%$ sequence similarity, all of the strains in the latter species exhibited nucleotide differences (substitutions, insertions or gaps) at up to 13 positions (depending on the strain) (data not shown). Hence, these represented seven different genotypes supported by a high bootstrap value (Fig. 2). All the strains linked to this species were shown to be metabolically and genomically diverse in previous studies (Supplementary Table S1 in IJSEM Online). The heterogeneous nature of these strains is in agreement with a previous report on strains of Mesorhizobium plurifarium isolated from L. leucocephala and Sesbania herbacea in Mexican soils (Wang et al., 2003). The relatively low sequence similarity of strain AC88c to Mesorhizobium chacoense, a Prosopis alba symbiont from Argentina (Velázquez et al., 2001) not previously reported from an African soil, suggests that this strain might represent a novel species.

Bradyrhizobium lineage. Compared with the large number of fast-growing rhizobial species, until recently only four species of Bradyrhizobium had been described (Bradyrhizobium japonicum, Bradyrhizobium elkanii, Bradyrhizobium yuanmingense and Bradyrhizobium liaoningense) (Sawada et al., 2003). However, by using several taxonomic techniques, such as numerical taxonomy, Biolog, SDS-PAGE, AFLP fingerprinting, and ITS and 16S rRNA gene sequencing, a large number of bradyrhizobia from various parts of the world have been studied, and several groups of strains with different phenotypic features and genomic profiles have been identified (Zhang et al., 1999b; van Berkum \& Fuhrmann, 2000; Lafay \& Burdon, 2001; Willems et al., 2001, 2003). In previous studies, we reported large metabolic and genomic diversity in 40 slow-growing strains isolated from eight different host species (Wolde-meskel et al., 2004b, c). Phylogenetic analysis of 21 representative strains in this study delineated eight distinct groups, in which 12 different partial 16S rRNA gene sequence types (genotypes) were represented (Fig. 2). All strains in groups I and VIII (except one strain in each) showed $100 \%$ partial sequence similarity to the type strains of Bradyrhizobium liaoningense and Bradyrhizobium elkanii, respectively (Table 1). Exceptions were strains AC86b2 (group I) and AC87b1 (group VIII), which had nucleotide substitutions at positions $29(\mathrm{~A} \rightarrow \mathrm{C})$ and $61(\mathrm{G} \rightarrow \mathrm{C})$, respectively. All strains in the other groups (II-VII) had novel sequences, but were closely related (99\%) to Bradyrhizobium japonicum or Bradyrhizobium yuanmingense. Interestingly, the extraslow-growing strains (Wolde-meskel et al., 2004a) in group II and the three others in group VII, which showed distinct metabolic and genomic profiles in previous studies (Table 1), also formed separate phylogenetic groups in this study (Fig. 2). The 16S rRNA gene 
of bradyrhizobia has been reported to show little variation (Barrera et al., 1997) and can be identical as, for example, Bradyrhizobium liaoningense and Bradyrhizobium japonicum (van Berkum \& Fuhrmann, 2000). Hence, RFLP or sequence analysis of this molecule may provide little discrimination. In view of this, and the high metabolic and genomic diversity of the test strains, which did not relate to reference species in earlier studies (Wolde-meskel et al., 2004b, c), our collection may represent a number of yet unrecognized taxa in the genus Bradyrhizobium, and further taxonomic analysis would be justified.

Methylobacterium strain. Phylogenetic analysis of an almost full-length (1387 bp) 16S rRNA gene sequence of AC72a, a strain from a root nodule of Phaseolus vulgaris, revealed that it belonged to the Methylobacterium lineage of the class 'Alphaproteobacteria' (Fig. 2). It showed $90 \%$ sequence similarity with Methylobacterium nodulans, the only symbiotic Methylobacterium species identified to date, from root nodules of Crotalaria sp. in Senegal (Sy et al., 2001). Other published closest phylogenetic neighbours in the genus were Methylobacterium organophilum (93\%) and Methylobacterium sp. strain F48 (94\%), suggesting that strain AC72a might represent another novel symbiotic species in the genus. The strain also formed a separate cluster using Biolog (Wolde-meskel et al., 2004b), 23S rRNA gene and combined 16S rRNA and 23S rRNA gene PCR-RFLP studies (Table 1 and Supplementary Figs S1 and S2 in IJSEM Online). Characteristically, AC72a was a fast-growing strain ( $>3 \mathrm{~mm}$ colony size in 2-3 days) on Yeast Mannitol Agar at $28^{\circ} \mathrm{C}$, which is in agreement with previous reports for strains belonging to Methylobacterium nodulans (Samba et al., 1999; Sy et al., 2001). However, poor growth occurred in liquid culture medium (yeast mannitol broth), even when a longer incubation time (up to 9 days) was used, after which characteristic pink-pigmented clumps in the solution were produced. In contrast to Methylobacterium nodulans, AC72a formed effective nodules on Vigna unguiculata and intermittently elicited nodules on Sesbania sesban and F. albida seedlings (data not shown). Although further phenotypic characterization of strain AC72a, and isolation and analysis of various nodulation genes are under way to establish whether the strain uses the same molecular mechanisms as rhizobia, our results emphasize that much greater diversity can be expected following the characterization of symbionts of unexplored legumes and by focusing on previously unexplored biogeographical areas.

\section{Symbionts of previously unexplored woody legume} species. Acacia abyssinica, Albizia gummifera. Erythrina brucei and Millettia ferruginea have been little studied, but are known to be locally important, indigenous woody legumes that have been integrated into traditional agroforestry systems in the highlands of Ethiopia as well as in East Africa (Hunde \& Thulin, 1989; Al Amin, 1990; Mbuya et al., 1994). This is the first reported phylogenetic analysis of isolates from these trees, and the results show associated rhizobia belonging to diverse groups. For example, strains of Acacia abyssinica were phylogenetically related to seven different rhizobial species in four genera (including Agrobacterium). It is interesting to note that a number of the strains associated with the trees were novel, with sequence similarities of $98-99 \%$ with the recognized species. In view of this and previous reports (Wolde-meskel et al., 2004b, c), which showed that there was a wide range of metabolic and genomic diversity that was not related to reference species, it is likely that several groups of these strains represent potentially novel species. The diversity shown in this study supports the view that long-term association between rhizobia and indigenous host species would allow gradual differentiation and diversity in the natural rhizobial population resident in the host's native soils (Andronov et al., 2003; Wang et al., 2003). Furthermore, the observed genetic diversity in indigenous rhizobial populations provides an opportunity to improve nitrogen fixation in agroforestry systems through the selection of efficient rhizobium-legume combinations.

\section{Comparative grouping of strains by using the various} methods. The $16 \mathrm{~S}$ rRNA gene PCR-RFLP pattern has been used to detect potential novel taxa of new isolates (Laguerre et al., 1994; Heyndrickx et al., 1996). It is also known that a longer stretch of the 16S rRNA gene (e.g. 800 instead of $300 \mathrm{bp}$ ) contains a conserved region that is sufficient to show the variation within groups of rootnodule bacteria, hence its frequent use to infer the phylogenetic affiliation of novel isolates (Terefework et al., 1998; Odee et al., 2002; Bala et al., 2003). In this study, by using $16 \mathrm{~S}$ rRNA gene PCR-RFLP, several subgroups were identified that had relatively low similarity (at most $85 \%$ ) to recognized species within the various genera (Fig. 1). This was also supported by the 23S rRNA gene and the combined PCR-RFLP pattern analyses results (Supplementary Figs S1 and S2 in IJSEM Online). However, strains representing distinct PCR-RFLP subgroups [for example, AC01b (16S rRNA PCR-RFLP genotype 6) and AC47c (genotype 12) in the Sinorhizobium branch; Fig. 1] showed $99-100 \%$ partial sequence similarity to the recognized species (Sinorhizobium saheli and Sinorhizobium fredii, respectively; Table 1). While the disparity of these methods in resolving the test rhizobial strains into species remains, the possibility that undetected differences might exist in the second $800 \mathrm{bp}$ stretch of the 16S rRNA gene cannot be excluded. Previously, various segments of the $16 \mathrm{~S}$ rRNA gene sequence have been reported to provide differing phylogenetic signals (Eardly et al., 1996).

van Berkum et al. (2003) reported discordant phylogenies within the rrn loci of rhizobia, after comparative analyses of groupings based on $16 \mathrm{~S}$ and $23 \mathrm{~S}$ rRNA gene sequences, resulting in different phylogenetic tree topologies for Rhizobium and Sinorhizobium species. Indeed, our $23 \mathrm{~S}$ rRNA gene PCR-RFLP data are in line with their findings, and the reference Sinorhizobium species used in this study were nested among Rhizobium strains (Supplementary 
Fig. S1 in IJSEM Online). It is also interesting to note the differences among grouping results obtained with the various approaches/methodologies used: Biolog and AFLP fingerprinting, ITS, $16 \mathrm{~S}$ and $23 \mathrm{~S}$ rRNA gene PCR-RFLP, and $16 \mathrm{~S}$ rRNA gene partial sequence analyses (Table 1 and Supplementary Table S1 in IJSEM Online). For example, strains representing 16S rRNA PCR-RFLP genotype 6 were grouped into each of three different groups of the $23 \mathrm{~S}$ rRNA and combined PCR-RFLP genotypes, whereas the same strains were grouped into four and two different Biolog and AFLP groups, respectively (Table 1). A similar situation has been reported in other studies (Wang et al., 2003), further demonstrating the necessity for polyphasic approaches in bacterial taxonomy.

In conclusion, by using metabolic and several modern molecular biological methodologies, we identified, within 195 rhizobial strains, several groups of rhizobia and a Methylobacterium strain that were not related to the recognized taxa. Phylogenetically, 34 out of 46 identified genotypes $(74 \%)$ represented novel partial $16 \mathrm{~S}$ rRNA gene sequence types, which related to six known genera. This wide phylogenetic diversity of the strains that were isolated from a relatively small number of leguminous species has further strengthened the views of other workers (Odee et al., 2002) that this sub-Saharan region might be an important centre of rhizobial biodiversity. Ethiopia, in particular, as the origin of several legumes and a centre of diversity for other plants, is a promising prospect for unearthing previously unidentified rhizobia that are more diverse and for elucidating the molecular evolution of rhizobium-legume symbiosis.

\section{ACKNOWLEDGEMENTS}

This work was funded by NUFU (Norwegian Universities Committee for Development Research and Education). E. W-m. is grateful to Lånekassen, Norway, for a $\mathrm{PhD}$ stipend and NorFA for providing a mobility scholarship. Thanks are due to all members of the nitrogen fixation research group at the Biocenter 1, University of Helsinki.

\section{REFERENCES}

Al Amin, H. M. (1990). Trees and Shrubs of the Sudan. Guildford \& King's Lynn, UK: Biddles.

Andronov, E. E., Terefework, Z., Roumiantseva, M. L. \& 7 other authors (2003). Symbiotic and genetic diversity of Rhizobium galegae isolates collected from the Galega orientalis gene center in the Caucasus. Appl Environ Microbiol 69, 1067-1074.

Anyango, B., Wilson, K. J., Beynon, J. L. \& Giller, K. E. (1995). Diversity of rhizobia nodulating Phaseolus vulgaris in two Kenyan soils of contrasting pHs. Appl Environ Microbiol 61, 4016-4021.

Bala, A. \& Giller, K. E. (2001). Symbiotic specificity of tropical tree rhizobia for host legumes. New Phytol 149, 495-507.

Bala, A., Murphy, P. \& Giller, K. E. (2002). Occurrence and genetic diversity of rhizobia nodulating Sesbania sesban in African soils. Soil Biol Biochem 34, 1759-1768.
Bala, A., Murphy, P. \& Giller, K. E. (2003). Distribution and diversity of rhizobia nodulating agroforestry legumes in soils from three continents in the tropics. Mol Ecol 12, 917-930.

Barrera, L. L., Trujillo, M. E., Goodfellow, M., Garcia, F. J., Hernández-Lucas, I., Dávila, G., van Berkum, P. \& MartínezRomero, E. (1997). Biodiversity of bradyrhizobia nodulating Lupinus spp. Int J Syst Bacteriol 47, 1086-1091.

Beyene, D., Kassa, S., Ampy, F., Asseffa, A., Gebremedhin, T. \& van Berkum, P. (2004). Ethiopian soils harbor natural populations of rhizobia that form symbioses with common bean (Phaseolus vulgaris L.). Arch Microbiol 181, 129-136.

Boom, R., Sol, C. J. A., Salimans, M. M. M., Jansen, C. L., Wertheimvan Dillen, P. M. E. \& van der Noordaa, J. (1990). Rapid and simple method for purification of nucleic acids. J Clin Microbiol 28, 495-503.

Chen, W.-M., Lee, T.-M., Lan, C.-C. \& Cheng, C.-P. (2000). Characterization of halotolerant rhizobia isolated from root nodules of Canavalia rosea from seaside areas. FEMS Microbiol Ecol 34, 9-16.

de Lajudie, P., Willems, A., Pot, B. \& 7 other authors (1994). Polyphasic taxonomy of rhizobia: emendation of the genus Sinorhizobium and description of Sinorhizobium meliloti comb. nov., Sinorhizobium saheli sp. nov., and Sinorhizobium teranga sp. nov. Int J Syst Bacteriol 44, 715-733.

de Lajudie, P., Willems, A., Nick, G. \& 9 other authors (1998). Characterization of tropical tree rhizobia and description of Mesorhizobium plurifarium sp. nov. Int J Syst Bacteriol 48, 369-382. de Lajudie, P., Willems, A., Nick, G. \& 7 other authors (1999). Agrobacterium bv. 1 strains isolated from nodules of tropical legumes. Syst Appl Microbiol 22, 119-132.

Doyle, J. J. (1994). Phylogeny of the legume family: an approach to understanding the origins of nodulation. Annu Rev Ecol Syst 25, 325-349.

Eardly, B. D., Wang, F.-S. \& van Berkum, P. (1996). Corresponding $16 \mathrm{~S}$ rRNA gene segments in Rhizobiaceae and Aeromonas yield discordant phylogenies. Plant Soil 186, 69-74.

Gao, J., Terefework, Z., Chen, W. \& Lindström, K. (2001). Genetic diversity of rhizobia isolated from Astragalus adsurgens growing in different geographical regions of China. J Biotechnol 91, $155-168$.

Giller, K. E. (2001). Nitrogen Fixation in Tropical Cropping Systems, 2nd edn, pp. 37, 222-250. Wallingford, UK: CAB International.

Heyndrickx, M., Vauterin, L., Vandamme, P., Kersters, K. \& de Vos, P. (1996). Application of combined amplified ribosomal DNA restriction analysis (ARDRA) patterns in bacterial phylogeny and taxonomy. J Microbiol Methods 26, 247-259.

Hunde, A. \& Thulin, M. (1989). Mimosoideae. In Flora of Ethiopia, vol. 3, pp. 71-96. Edited by M. Hedberg \& S. Edwards. Addis Ababa, Ethiopia: The National Herbarium.

Janeca, J., Jenkins, M. B., Brackett, N. S., Lion, L. W. \& Ghiorse, W. C. (2002). Characterization of Sinorhizobium isolate and its extracellular polymer implicated in pollutant transport in soil. Appl Environ Microbiol 68, 423-426.

Khbaya, B., Neyra, M., Normand, P., Zerhari, K. \& Filali-Maltouf, A. (1998). Genetic diversity and phylogeny of rhizobia that nodulate Acacia spp. in Morocco assessed by analysis of rRNA genes. Appl Environ Microbiol 64, 4912-4917.

Kumar, S., Tamura, K., Jakobsen, I. B. \& Nei, M. (2001). MEGA2: molecular evolutionary genetics analysis software. Bioinformatics $\mathbf{1 7}$, 1244-1245.

Lafay, B. \& Burdon, J. J. (2001). Small-subunit rRNA genotyping of rhizobia nodulating Australian Acacia spp. Appl Environ Microbiol 67, 396-402. 
Laguerre, G., Allard, M.-R., Revoy, F. \& Aarger, N. (1994). Rapid identification of rhizobia by restriction fragment length polymorphism analysis of PCR-amplified 16S rRNA genes. Appl Environ Microbiol 60, 56-63.

Martínez-Romero, E. \& Caballero-Mellado, J. (1996). Rhizobium phylogenies and bacterial genetic diversity. Crit Rev Plant Sci 15, 113-140.

Mbuya, L. P., Msanga, H. P., Ruffo, C. K., Birnie, A. \& Tengnäs, Bo. (1994). Useful Trees and Shrubs for Tanzania: Identification, Propagation and Management for Agricultural and Pastoral Communities. Nairobi, Kenya: Regional Soil Conservation Unit (RSCU), Swedish International Development Authority.

McInroy, S. G., Campbell, C. D., Haukka, K. E., Odee, D. W., Sprent, J. I., Wang, W.-J., Young, J. P. W. \& Sutherland, J. M. (1999). Characterisation of rhizobia from African acacias and other tropical woody legumes using Biolog and partial 16S rRNA sequencing. FEMS Microbiol Lett 170, 111-117.

Moreira, F. M. S., Haukka, K. \& Young, J. P. W. (1998). Biodiversity of rhizobia isolated from a wide range of forest legumes in Brazil. Mol Ecol 7, 889-895.

Nick, G., de Lajudie, P., Eardly, B. D., Suomalainen, S., Paulin, L. Zhang, X., Gillis, M. \& Lindström, K. (1999). Sinorhizobium arboris sp. nov. and Sinorhizobium kostiense sp. nov., isolated fromleguminous trees in Sudan and Kenya. Int J Syst Bacteriol 49, 1359-1368.

Normand, P., Cournoyer, B., Simonet, P. \& Nazaret, S. (1992). Analysis of a ribosomal operon in the actinomycete Frankia. Gene 111, 119-124.

Odee, D. W., Sutherland, J. M., Msksyisni, E. T., Mclnroy, S. G. \& Sprent, J. I. (1997). Phenotypic characteristics and composition of rhizobia associated with woody legumes growing in diverse Kenyan conditions. Plant Soil 188, 65-75.

Odee, D. W., Haukka, K., McInroy, S. G., Sprent, J. I., Sutherland, J. M. \& Young, J. P. W. (2002). Genetic and symbiotic characterization of rhizobia isolated from tree and herbaceous legumes grown in soils from ecologically diverse sites in Kenya. Soil Biol Biochem 34, 801-811.

Raven, P. H. \& Polhill, R. M. (1981). Biography of the Leguminosae. In Advances in Legume Systematics, part 1, pp. 27-34. Edited by R. M. Polhill \& P. H. Raven. Kew, UK: Royal Botanic Gardens.

Salmassi, T. M., Venkateswaren, K., Satomi, M., Neolson, K. H., Newman, D. K. \& Hering, J. G. (2002). Oxidation of arsenite by Agrobacterium albertimagni, AOL15, sp. nov., isolated from Hot Creek, California. Geomicrobiol J 19, 53-66.

Samba, R. T., de Lajudie, P., Gillis, M., Neyra, M., Barreto, M. M. S. \& Dreyfus, B. (1999). Diversity of rhizobia nodulating Crotalaria spp. from Senegal. Symbiosis 27, 259-268.

Sawada, H., Kuykendall, L. D. \& Young, J. M. (2003). Changing concepts in the systematics of bacterial nitrogen-fixing legume symbionts. J Gen Appl Microbiol 49, 155-179.

Somasegaran, P. \& Hoben, H. J. (1994). Handbook for Rhizobia: Methods in Legume - Rhizobium Technology. New York: Springer.

Stackebrandt, E. \& Goebel, B. M. (1994). Taxonomic note: a place for DNA-DNA reassociation and 16S rRNA sequence analysis in the present species definition in bacteriology. Int J Syst Bacteriol 44, 846-849.

Sy, A., Giraud, E., Jourand, P. \& 8 other authors (2001). Methylotrophic Methylobacterium bacteria nodulate and fix nitrogen in symbiosis with legumes. J Bacteriol 183, 214-220.

Terefework, Z., Nick, G., Suomalainen, S., Paulin, L. \& Lindström, K. (1998). Phylogeny of Rhizobium galegae with respect to other rhizobia and agrobacteria. J Biotechnol 48, 349-356.

Terefework, Z., Kaijalainen, S. \& Lindström, K. (2001). AFLP fingerprinting as a tool to study the genetic diversity of Rhizobium galegae isolated from Galega orientalis and Galega officianlis. J Biotechnol 91, 169-180.

Thompson, J. D., Gibson, T. J., Plewniak, F., Jeanmougin, F. \& Higgins, D. G. (1997). The CLUSTAL_X Windows interface: flexible strategies for multiple sequence alignment aided by quality analysis tools. Nucleic Acids Res 25, 4876-4882.

Toledo, I., Lloret, L. \& Martínez-Romero, E. (2003). Sinorhizobium americanus sp. nov., a new Sinorhizobium species nodulating native Acacia spp. in Mexico. Syst Appl Microbiol 26, 54-64.

van Berkum, P. \& Fuhrmann, J. (2000). Evolutionary relationships among the soybean bradyrhizobia reconstructed from 16S rRNA gene and internally transcribed spacer region sequence divergence. Int J Syst Evol Microbiol 50, 2165-2172.

van Berkum, P., Beyene, D., Bao, G., Campbell, T. A. \& Eardly, B. D. (1998). Rhizobium mongolense sp. nov. is one of three rhizobial genotypes identified which nodulate and form nitrogen-fixing symbioses with Medicago ruthenica [(L.) Ledebour]. Int J Syst Bacteriol 48, 13-22. van Berkum, P., Terefework, Z., Paulin, L., Suomalainen, S., Lindström, K. \& Eardly, D. (2003). Discordant phylogenies within the rrn loci of rhizobia. J Bacteriol 185, 2988-2998.

Velázquez, E., Igual, J. M., Willems, A. \& 9 other authors (2001). Mesorhizobium chacoense sp. nov., a novel species that nodulates Prosopis alba in the Chaco Arido region (Argentina). Int J Syst Evol Microbiol 51, 1011-1021.

Wang, S. Y. \& Chen, W. X. (1996). Numerical taxonomy and DNA relatedness of rhizobia isolated from Astagalus spp. In Diversity and Taxonomy of Rhizobia, pp. 79-84. Edited by F. D. Li, T. A. Lie, W. X. Chen \& J. C. Zhou. Beijing: China Agricultural Scientech Press.

Wang, E. T. \& Martínez-Romero, E. (2000). Sesbania herbaceaRhizobium huautlense nodulation in flooded soils and comparative characterization of $S$. herbacea-nodulating rhizobia in different environments. Microbial Ecol 41, 25-32.

Wang, E. T., Martínez-Romero, J. \& Martínez-Romero, E. (1999). Genetic diversity of rhizobia from Leucaena leucocephala nodules in Mexican soils. Mol Ecol 8, 711-724.

Wang, E. T., Kan, F. L., Tan, Z. Y., Toledo, I., Chen, W. X. \& MartínezRomero, E. (2003). Diverse Mesorhizobium plurifarium populations native to Mexican soils. Arch Microbiol 180, 444-454.

Weisburg, W. G., Barns, S. M., Pelletier, D. A. \& Lane, D. J. (1991). $16 \mathrm{~S}$ ribosomal DNA amplification for phylogenetic study. J Bacteriol 173, 697-703.

Willems, A., Doignon-Bourcier, F., Gillis, M. \& de Lajudie, P. (2001). Evaluation of AFLP for the grouping of Bradyrhizobium strains. Genet Sel Evol 33 (Suppl. 1) S365-S377.

Willems, A., Munive, A., de Lajudie, P. \& Gillis, M. (2003). In most Bradyrhizobium groups sequence comparison of 16S-23S rDNA internal transcribed spacer regions corroborates DNA-DNA hybridizations. Syst Appl Microbiol 26, 203-210.

Wolde-meskel, E., Berg, T., Peters, N. K. \& Frostegård, A. (2004a). Nodulation status of native woody legumes, and phenotypic characteristics of associated rhizobia in soils of southern Ethiopia. Biol Fertil Soils 40, 55-66.

Wolde-meskel, E., Terefework, Z., Lindström, K. \& Frostegård, Å. (2004b). Metabolic and genomic diversity of rhizobia isolated from field standing native and exotic woody legumes in southern Ethiopia. Syst Appl Microbiol 27, 603-611.

Wolde-meskel, E., Terefework, Z., Lindström, K. \& Frostegård, A. (2004c). Rhizobia nodulating African Acacia spp. and Sesbania sesban trees in southern Ethiopian soils are metabolically and genomically diverse. Soil Biol Biochem 36, 2013-2025.

Young, J. P. W. \& Haukka, K. E. (1996). Diversity and phylogeny of rhizobia. New Phytol 133, 87-94. 
Young, J. M., Kuykendall, L. D., Martínez-Romero, E., Kerr, A. \& Sawada, H. (2001). A revision of Rhizobium Frank 1889, with an emended description of the genus, and the inclusion of all species of Agrobacterium Conn 1942 and Allorhizobium undicola de Lajudie et al. 1998 as new combinations: Rhizobium radiobacter, R. rhizogenes, $R$. rubi, $R$. undicola and $R$. vitis. Int J Syst Evol Microbiol 51, 89-103.

Zhang, X., Harper, R., Karsisto, M. \& Lindström, K. (1991). Diversity of Rhizobium bacteria isolated from the root nodules of leguminous trees. Int J Syst Bacteriol 41, 104-113.
Zhang, X.-X., Guo, X.-W., Terefework, Z., Paulin, L., Cao, Y.-Z., Hu, F.-R., Lindström, K. \& Li, F.-D. (1999a). Genetic diversity among rhizobial isolates from field-grown Astragalus sinicus of Southern China. Syst Appl Microbiol 22, 312-320.

Zhang, X., Nick, G., Kaijalainen, S., Terefework, Z., Paulin, L., Tighe, S. W., Graham, P. H. \& Lindstrom, K. (1999b). Phylogeny and diversity of Bradyrhizobium strains isolated from the root nodules of peanut (Arachis hypogaea) in Sichuan, China. Syst Appl Microbiol 22, 378-386. 